\title{
Development of Digital Interface for Waterway Service Support Application in Amazonas
}

\section{Desenvolvimento de Interface Digital para Aplicativo de Suporte de Serviço Aquaviário no Amazonas}

Tiago Kimura Bentes, Universidade Federal do Amazonas.

tiago.kimura@gmail.com

Nelson Kuwahara, Universidade Federal do Amazonas.

nelsonk@ufam.edu.br

\begin{abstract}
More than one-third of the largest freshwater basin on the planet is located within the state of Amazonas. As the region is crossed by rivers, waterway transportation assumes a role not only of locomotion, but of supply, communication, and connection between the municipalities. Despite the great importance that river navigation has, there were few technological advances applied to facilitate the undertaking of activities within the sector. Considering this context, this article intends to elaborate a proposal of a mobile application interface for buying and selling regional boat tickets. To carry out this research, the Project E project method (MEURER and SZABLUK, 2010) was applied to understand the structure of the ticket sales service and to develop a digital interface with functions that would collaborate with the execution and modernization of the ticket sales service. The result was an easy-to-navigate graphical user interface rated as good and excellent by the users who tested it.
\end{abstract}

Keywords: Interface design, User experience, Tickets selling, Water transportation, Amazon boats

\section{Resumo}

Mais de um terço da maior bacia de água doce do planeta está localizada no estado do Amazonas. Como a região é cortada por rios, o transporte aquaviário assume um papel não só de locomoção, mas de abastecimento, comunicação e conexão entre os municípios. Apesar da grande importância que tem a navegação fluvial, poucos foram os avanços tecnológicos aplicados para facilitar o desenvolvimento das atividades do setor. Diante desse contexto, este artigo pretende elaborar uma proposta de interface de aplicativo móvel para compra e venda de passagens de barcos regionais. Para realizar esta pesquisa, o método do Projeto E (MEURER e SZABLUK, 2010) foi aplicado para entender a estrutura do serviço de venda de ingressos e desenvolver interface digital com funções que colaboram com a execução e modernização do serviço de venda de ingressos. $\mathrm{O}$ resultado foi uma interface gráfica de usuário fácil de navegar, classificada como boa e excelente pelos usuários que a testaram.

Palavras-chave: Design de interface, Experiência de usuário, Venda de passagens, Transporte Hidroviário, Barcos Amazônicos. 


\section{Introduction}

Despite the importance that the river modality has for the region, this sector has functioned until now without proper regulation, presenting social and environmental difficulties and with few technological investments (FERREIRA, 2016). By making a comparison in 2008 with the boats used at the time of rubber plantations, Frota (2008) observed that little had changed. In 2018 (ten years later), it is possible to see that competitiveness with vessels from other states together with the needs of the target public caused changes in the typologies of vessels in the main sections, as portrayed by Ferreira (2016), or caused the emergence of the segment of jet boats, due to the need to move faster, as portrayed by David (2010).

When comparing the technological scenario of the river sector with different modes of transportation, such as air for example, the inferiority in technological development is noticeable, in such a way that services taking into account digital and physical interfaces play an important role related to organizational and competitive advantages of companies, as according to Costa, Holder and Mackinnon (2017), more usable interfaces tend to improve effectiveness, efficiency, productivity, acceptance and reputation, well-being, satisfaction, accessibility and sustainability by counteracting possible adverse effects on user health, safety and performance, decreasing error propensity and the need for training, adding value to services by making passenger experiences enjoyable.

The use of Information and Communication Technology (ICTs) within companies and in the transportation sector as a tool to help and distribute information is a fact consolidated in society since 1970 and fostered every technological innovation launched annually for the population. These ICTs make ships tasks easier and ultimately change the relationship customers have with companies, creating a new, increasingly demanding and informed consumer model (MARSILIO, 2014). Thus, the scarce presence of ICT on Amazonian vessels directly affects shipowners, as they perform administrative activities in a complex environment practically by hand, as observed by Moura (2017), also affecting passengers' experiences at the information, qualitative and emotional levels.

Given this scenario, it is necessary to collaborate so that the services provided are in accordance with article 28 of Law 10233/2001 and article 6 of Law 8.987/1995 that regulate the quality of service rendering according to the attributes of: regularity, continuity, efficiency, safety, timeliness, generality, courtesy and modality of tariffs, where the current attribute refers to the modernity of techniques, equipment and facilities and their conservation, as well as the improvement and expansion of the service (MEREGE, 2011).

Considering the foregoing arguments, one realizes the extreme need for river waterway passenger service providers to know how to satisfy their customers and, at the same time, to manage productive, profitable and competent staffed operations (FROTA, 2008; ANTAQ, 2018).

Given the need for technological innovation and improvement in the quality of river navigation services in the northern region, design acts in this context as an innovative agent with the tangibility of services through interfaces, helping the execution of these services, ensuring a better experience for both passengers and vessel owners by optimizing, streamlining and integrating processes, helping to improve the industry. 


\section{Characterization of Amazonian regional river transport}

Passenger transport by boat is largely responsible for changes in mobility levels in municipalities in the countryside of the state, circulating people and products and inducing local development. There are several studies that denounce the inadequacy of river transport due to precariousness and inefficiency (FROTA, 2008; CALHEIROS, 2010; BARBOSA, SANTOS and KUWAHARA, 2015; MOURA, 2017).

\section{Main features of Amazonian vessels}

Colloquially, boats in the Amazon can be called "Motor", "Boat", "Recreational" or "Regional Boats". They have an economic-logistical function and have a social nature, since they are largely responsible for supply and communication among the riverside communities of the region.

This type of vessel, according to the National Waterway Transportation Agency - ANTAQ (2017), is the most adapted to the cargo and passenger conditions to operate in the tributaries of the Amazon River.

The boats have a characteristic design such as the hull compatible with the water depth, dimensions compatible with the lanes. The waterway, propeller protection and hull appendages must be easy to conduce, have wide visibility in the cockpit, uncoupling features, radar and spotlight to face the varying navigability conditions of Amazonian rivers. They are built in various sizes, in regional native wood or iron, although today the boats in the main sections have iron hulls, reducing the number of boats with wooden hull, are used to transport cargo and passengers by the navigable waterways of the Amazonian territory (BENCHIMOL, 1995; CALHEIROS, 2010; MORAES, 2013; FERREIRA, 2016; MOURA, 2017).

The playgrounds are equipped with a single hull, powered by diesel engines, reaching approximately 25 kilometers per hour. They have an average length of 26 meters. The vessel's cross-sectional width, measured from one edge to the other, averages 6 meters; In relation to the draft, which is the depth measurement at the lowest point of a vessel's keel in relation to the waterline, it is less than 2 meters. This facilitates navigation even during drought periods. (MOURA, 2017)

The average age of construction of these vessels is 13 years, the average total length of 28 meters, average length of 7 meters and average carrying capacity of 150 passengers.

\section{Channels adopted for offering and selling services}

In Manaus capital of the state of Amazonas, most passengers buy their ticket with agents / ticket sellers in the Manaus Moderna Port (PMM), because it is the cheapest ticket price than in the travel agencies, another factor is the ease of loading and unloading of cargo and passengers, 
which is done more quickly and has no fee for the volume of cargo. The ticket sold at the Manaus Organized Port ticket stall (POM - privatized port) is fixed ( $\mathrm{R} \$ 100.00)$. However, in PMM there is a variation of $R \$ 50.00$ to $R \$ 100.00$, depending on the competition with Pará's boats. The earlier the better the places for hammocks, because of this, at dawn the passengers begin to arrive and generally wait inside the vessel, from 0 to 9 o'clock for the effective departure. As with this type of transport it is not necessary to purchase the ticket in advance, it is common for most passengers not to know the duration of the trip and departure times of the vessel (LINS, CAMELO and DACOL 2007; BARBOSA and PRADO, 2014; FERREIRA, 2016).

As for the ease of purchase of the ticket, it is clear that this is a common practice of river passenger service providers. Direct and indirect ticket sales through agents are common. These usually get passengers at high flow locations near the mooring points of vessels. There is still no organized ticketing system in this sector (ANTAQ, 2015).

\section{Profile of service requires}

According to data from the Brazilian Institute of Geography and Statistics, the northern region of the country concentrates about $9 \%$ of the Brazilian population (17,936,201 inhabitants) and $45 \%$ of the Brazilian territory. The 2016 average monthly nominal household income per capita in the North Region was R \$ 846.00, about 50\% lower than the average income of the state of São Paulo, which has the highest value in the country. In the national comparison, the average income of the population of the Northern Region is $34 \%$ lower than the income registered for the national aggregate. (ANTAQ, 2017)

A survey conducted by ANTAQ (2015) identified the profile of users of regional waterway transport in the Amazon, and found that:

- Regarding gender, most of the public is male, $49.9 \%$ female and $59.1 \%$ male.

- Regarding age distribution, $52.1 \%$ of service users are grouped in the young age group, from 16 to 35 years old.

- In relation to family income, $93.3 \%$ of users have a monthly family income of up to 5 minimum wages (R \$ 3,620.00), an even lower rate than the National Household Sample Survey (PNAD), highlighting the social importance of river transport.

- As for frequency, $21.5 \%$ of passengers surveyed use the river mode continuously (at least one trip per month) and $31 \%$ travel at least once every six months.

- For $49.5 \%$ of travelers, the main reason for travel is Leisure / Recreation such as visiting friends / relatives or tourism, while $44 \%$ travel for work, health or study.

As for connectivity in the northern region, the Brazilian Institute of Geography and Statistics IBGE (2018) finds that $72 \%$ of households have access to the internet, with $89.7 \%$ being mobile broadband. Of Brazil's regions, the north is the one that most accesses the internet by cell phone, with an index of $99.2 \%$. However, there is still a shortage of fixed network infrastructure since the lowest rate of fixed broadband internet is north of the country. Among people who do not have access to the internet, $26.6 \%$ say they lack interest, and $25.2 \%$ due to lack of signal coverage. 
According to IBGE (2018), it is not easy to estimate the reach areas of the mobile network, but Figure 1 shows that, despite the areas without coverage, the main cities of the stretch have good coverage of mobile internet bandwidth.

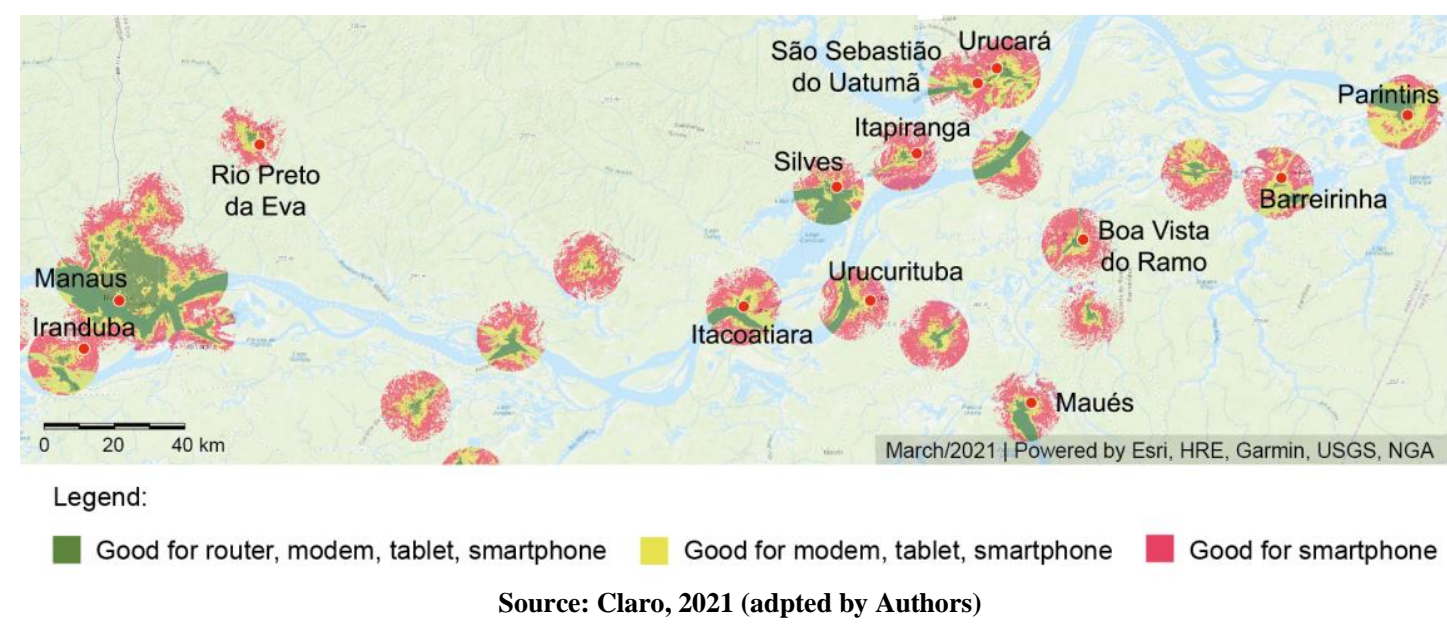

Figure 1: 3G network coverage of Claro operator in the Manaus / Parintins section

Although mobile internet coverage does not reach most of the waterway stretches, the application's operation would not be compromised, as the main features designed would be for use in an urban area, where the majority of the population in the northern region has access to home internet.

\section{Materials and Methods}

For the development of the interface proposal, the Project E method adapted was used, which aims to guide and optimize user-friendly graphic interface designs for different interactive systems and products (MEURER and SZABLUK, 2010). It is a non-sequential method, modifiable to meet the requirements of each project. It has six steps.

$1^{\text {st }}$. Strategy, which aims to understand the context of the project

$2^{\text {nd }}$. Scope, which seeks to define the functionality of the interface

$3^{\text {rd }}$. Structure, focusing on artistic design and generation of the first alternatives

$4^{\text {th }}$. Skeleton aims at the structural organization of the application with the aid of wireframes

$5^{\text {th }}$. Aesthetics seeks an aesthetically well resolved and balanced result

$6^{\text {th }}$. Execution, where the use and implementation tests are performed

Meurer and Szabluk (2010) state that it is possible to change the procedures of one or more steps to restructure, reorganize, reuse and re-plan alternatives to benefit the final result. Therefore, 
the Structure and Skeleton steps were performed simultaneously because they address aspects in which the results are directly related.

In the strategy stage, the first procedure performed was the "Design Questions" (MEURER and SZABLUK, 2010), which aims to answer the fundamental questions for understanding the project context such as: "What to develop?", "Why design?", "How to design", "Who to design for?" and "What technology will be used?"

Another technique used in the same step was the "Current Condition and Desired Condition" (MEURER and SZABLUK, 2010) which aims to set goals and plan project actions by analysing what state a current system is in, what its tools and usage characteristics are to define a desired scenario for the enhancements and new features that the product will have, according to the design requirements. For the case of this paper, the best way to represent the current condition and the intended condition was by using an adaptation of the User Journey Map (STICKDORN and SCHNEIDER, 2014), made as an organization chart under a timeline that records the process ticket sales and their main subjects.

The Person Definition technique, according to Stickdorn and Schneider (2014), is about creating fictitious profiles designed to represent a specific group of people based on their common interests, which will guide design teams. These profiles are created from research insights and hard data, and should not be an activity based on cartoons or inventions. The personas profile was defined based on the statistical reports on passenger profiles released (ANTAQ, 2013).

The strategy stage's last technique was a feature comparison (MEURER and SZABLUK, 2010), which compares the most relevant features in the systems analyzed. To choose the apps analyzed, searches were done in online search engines and in-app stores of the two major mobile operating systems (IOS: App Store and Android: Play Store) for apps with the same purpose and functionality as the intended development. The survey returned five applications/websites. (a) "NetBarco", (b) "Canoeiro", (c) "Naveggar", (d) "Transporte Fluvial Manaus" and (e) "Embarcar". From the results obtained, the criteria (i) similarity to the project objective and (ii) ease of access to the system use for testing were used to select the applications (a) NetBarco and (e) Embarcar.

In the scope stages, from the information obtained, the organization chart of the application structure was built. Listing the functions and function of each screen considering a hierarchy of information.

Wireframes are preliminary sketches of the product screens, where you can observe the structure, organization and nature of the elements and the hierarchy and density of the information. They can be of high or low fidelity depending on the need of the project or what is intended to test (ROTH et al., 2017). Wireframes were used to study the navigability components and, simultaneously, the screens' drawings in the structure and skeleton stages.

The designed wireframes were used in a pilot usage test to verify that this interface was usable. The pilot test was conducted on the UseBerry online platform, which allows you to simulate the online application and records task completion time, heat map, and direct / indirect success information, allowing further analysis. In this test, users were asked to complete consecutive tasks 
to gain insights and familiarize themselves with the platform. This step was applied to 2 people who partially met the parameters defined by the generated persona.

The activities requested in the pilot test were. $1^{\text {st }}$ ) Imagine that you are in Manaus / Amazonas and decide to go to Parintins (a city located to the west in the state of Amazonas) to take your 9year-old niece to visit family members from April 3 to 7, 2020; $2^{\text {nd }}$ ) select the cheapest ticket for the outward journey; $3^{\text {rd }}$ ) register the passengers; and $4^{\text {th }}$ ) finalize the purchase.

The visual aspects of the application were defined from the construction of a moodboard with images that illustrate the context of vessels and features that could generate inspirations for visual identity such as colours and typography. From the defined identity, an image definition study was carried out using interface components to verify how the graphic elements would behave.

Finally, an interface model was generated considering all the results from the previous steps. To validate the interface, a new usage test was applied on the same platform used for the pilot test with 10 people that fit the profile generated by the persona.

This time, the tasks requested in this new usage test were divided into more steps to facilitate memorization, as follows. $1^{\text {st }}$ ) Insert Manaus as source and Parintins as destination; $2^{\text {nd }}$ ) Set the departure dates for 02/04/2020 and the return on 07/04/2020; $3^{\text {rd }}$ ) Set the number of passengers to 2 , one 25 years old and one 9 years old; $4^{\text {th }}$ ) Select the cheapest possible ticket for the round trip; $5^{\text {th }}$ ) Register the passengers; $6^{\text {th }}$ ) Enter the payment method and finalize the purchase.

At the end of the usage test, a questionnaire was applied to verify $1^{\text {st }}$ ) which task was more difficult to perform; $2^{\text {nd }}$ ) What is the opinion about the graphical interface; and $3^{\text {rd }}$ ) what is the final evaluation of the application.

\section{Results}

Figure 2 shows the result of applying the technique of design issues, thanks to this technique, it is possible to visualize in general the basic implications of the project.

\begin{tabular}{|l|l|}
\hline \multicolumn{1}{|c|}{ Question } & \multicolumn{1}{c|}{ Answer } \\
\hline What should be developed? & $\begin{array}{l}\text { A mobile application interface to assist in the process of } \\
\text { buying and selling mixed boat tickets in Manaus - Parintins. }\end{array}$ \\
\hline Why design? & $\begin{array}{l}\text { Because of the problems observed in preliminary research, } \\
\text { which are: } \\
\text { Lack of control and estimation of passenger capacity on } \\
\text { each trip; provide remote control and facilitate } \\
\text { communication of prices, availability, travel dates and } \\
\text { service offered; possibility of fraud; facilitate compliance } \\
\text { with regulatory agency standards; encourage technological } \\
\text { development in the regional river sector; facilitate the } \\
\text { purchase and sale of boat tickets. }\end{array}$ \\
\hline How should it be designed? & $\begin{array}{l}\text { Using the project method "Project E" and techniques } \\
\text { suggested by (MEURER and SZABLUK, 2010). }\end{array}$ \\
\hline For who? & $\begin{array}{l}\text { Shipowners and Passengers of mixed transport vessels in } \\
\text { Amazonas. }\end{array}$ \\
\hline
\end{tabular}


\begin{tabular}{|l|l|}
\hline $\begin{array}{l}\text { What technologies will be } \\
\text { used? }\end{array}$ & $\begin{array}{l}\text { Features present in smartphones such as sensors, GPS, data } \\
\text { transfer technologies, camera. }\end{array}$ \\
\hline
\end{tabular}

Figura 1: Design Issues Technique Result

Figure 3 shows the current state of the service in the form of a user journey map. For this map, 5 important phases were identified. $1^{\text {st }}$ ) search and planning, which, for the shipowner, is the time to plan dates, future travel prices and distribute tickets to outside vendors, and for the passenger it is when looking for available travel information; $2^{\text {nd }}$ ) buying and selling, is the moment when the actual financial transaction happens, most of the time it happens directly between the passenger and the ticket seller; $3^{\text {rd }}$ ) Preparation, this is the moment when the passenger goes to the boat and meets the check-in protocols, it is also the phase when the shipowner receives money from tickets sold by external sellers and pays commissions; $4^{\text {th }}$ ) trip, only during the trip does the owner check the tickets approaching the passengers and asking them to add their name to the captaincy's passenger list; $5^{\text {th }}$ ) Arrival is the moment when the passenger leaves the vessel and the cycle repeats itself from the buying and selling stage.

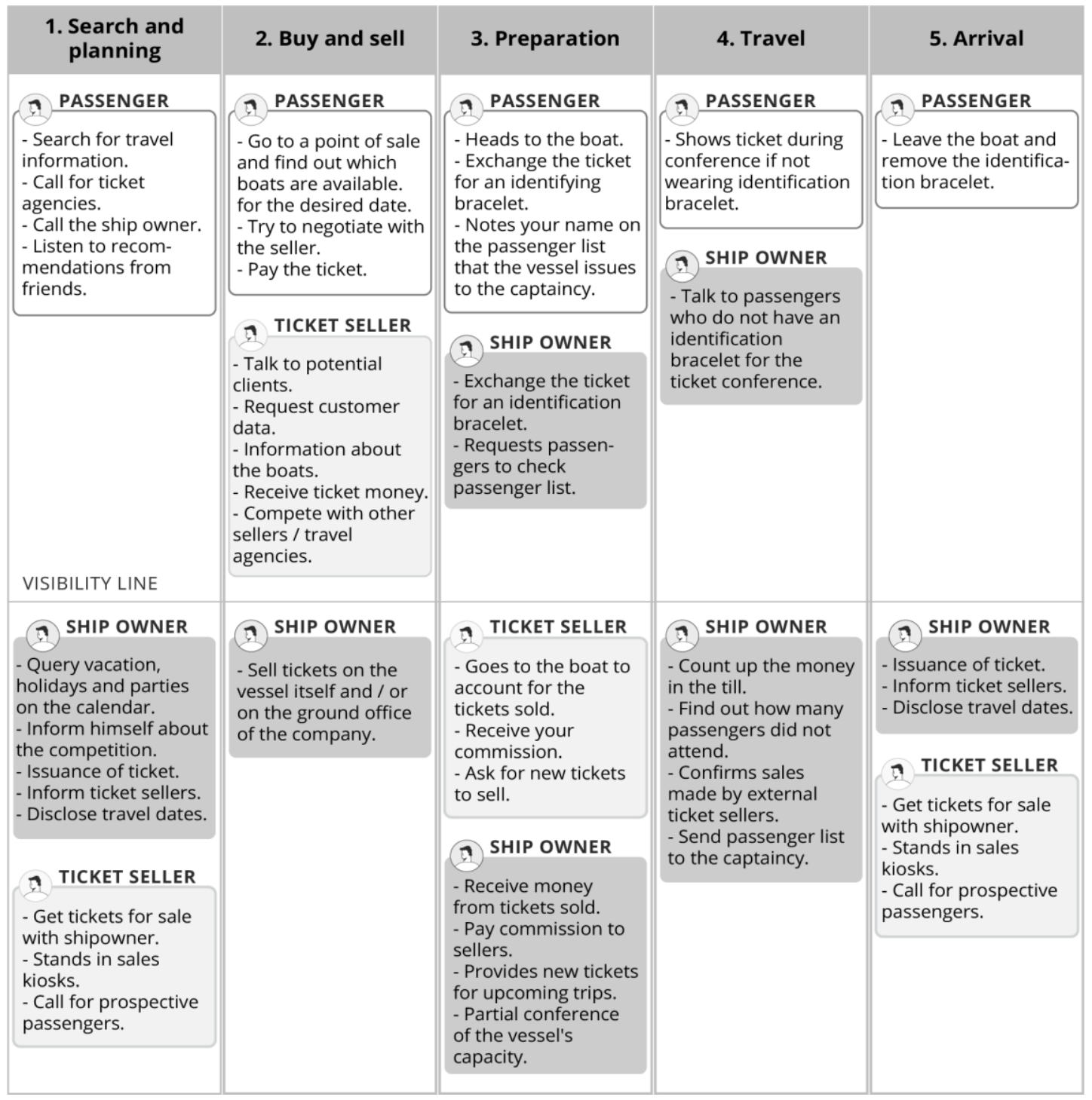

Figure 3: Current Conditions - User Journey Map 
Thanks to this tool it was possible to realize the number of tasks performed and the fact that the first contact of the passenger with the shipping company is made by an external ticket vendor, who has no employment relationship and therefore serves several other vessels too. It should also be noted that the shipowner relies on the accountability of the ticket seller before the boat sets off to receive money for the tickets sold.

Ideal conditions are shown in Figure 4. The first thing to note is the exclusion of some activities due to the automation that the application will offer. At the time of preparation, the ship's owner could identify the most searched dates and plan trips for days ahead of big events like shows or fairs. The data that the application provides to the owner contributes to strategic planning. Passengers will be able to buy tickets without having to travel to the port, as well as be able to follow promotions that were previously absent. The ticket seller is still present at the time of purchase for those who prefer to buy the ticket in person, but there was no longer a need to go to the boat to receive his commission, which would be passed on soon after the purchase.

\begin{tabular}{|c|c|c|c|c|}
\hline $\begin{array}{l}\text { 1. Search and } \\
\text { planning }\end{array}$ & 2. Buy and sell & 3. Preparation & 4. Travel & 5. Arrival \\
\hline $\begin{array}{l}\text { PASSENGER } \\
\text { - Search for travel } \\
\text { information. } \\
\text { - Call for ticket } \\
\text { agencies. } \\
\text { - Call the ship owner. }\end{array}$ & $\begin{array}{l}\text { PASSENGER } \\
\text { - Purchase the ticket } \\
\text { through the app. } \\
\text { - Print ticket or save } \\
\text { to phone. }\end{array}$ & $\begin{array}{l}\text { PASSENGER } \\
\text { - Heads to the boat. } \\
\text { - Passes the QR } \\
\text { Code reader and } \\
\text { receives a bracelet. }\end{array}$ & & $\begin{array}{l}\text { PASSENGER } \\
\text { - Leave the boat and } \\
\text { remove the } \\
\text { identification } \\
\text { bracelet. }\end{array}$ \\
\hline $\begin{array}{l}\text { friends. } \\
\text { - Consult in-app } \\
\text { suggestions and } \\
\text { promotions. }\end{array}$ & $\begin{array}{l}\text { TICKET SELLER } \\
\text { - Talk to potential } \\
\text { customers. } \\
\text { - Request customer } \\
\text { data. } \\
\text { - Gives information } \\
\text { about the boats. } \\
\text { - Compete with } \\
\text { other sellers. } \\
\text { - Get commission on } \\
\text { tickets sold by the } \\
\text { app. }\end{array}$ & $\begin{array}{l}\text { SHIP OWNER } \\
\text { - Ask passengers to } \\
\text { read the QR Code } \\
\text { and place the } \\
\text { identification tag on } \\
\text { the passenger. }\end{array}$ & & \\
\hline VISIBILITY LINE & & & & \\
\hline $\begin{array}{l}\text { SHIP OWNER } \\
\text { - Query period most } \\
\text { searched dates and } \\
\text { average price of } \\
\text { competition in the } \\
\text { app. } \\
\text { - Consult indications } \\
\text { of upcoming events. } \\
\text { - Analyzes the } \\
\text { possibility of making } \\
\text { promotions. } \\
\text { - Schedule tickets. }\end{array}$ & $\begin{array}{l}\text { SHIP OWNER } \\
\text { - Sell tickets on the } \\
\text { vessel itself and / or } \\
\text { on the ground office } \\
\text { of the company. } \\
\text { - Receive money from } \\
\text { tickets sold. }\end{array}$ & $\begin{array}{l}\text { SHIP OWNER } \\
\text { - Partial checking of } \\
\text { passenger numbers. } \\
\text { - Generates } \\
\text { passenger list for } \\
\text { captaincy by app } \\
\text { before departure. }\end{array}$ & & $\begin{array}{l}\text { (9) SHIP OWNER } \\
\text { - Schedule tickets. }\end{array}$ \\
\hline
\end{tabular}


Figure 5 presents the result of the personas creation technique. For this article a passenger profile was developed based on the latest characterization made by the National Waterway Transportation Agency (ANTAQ, 2013).

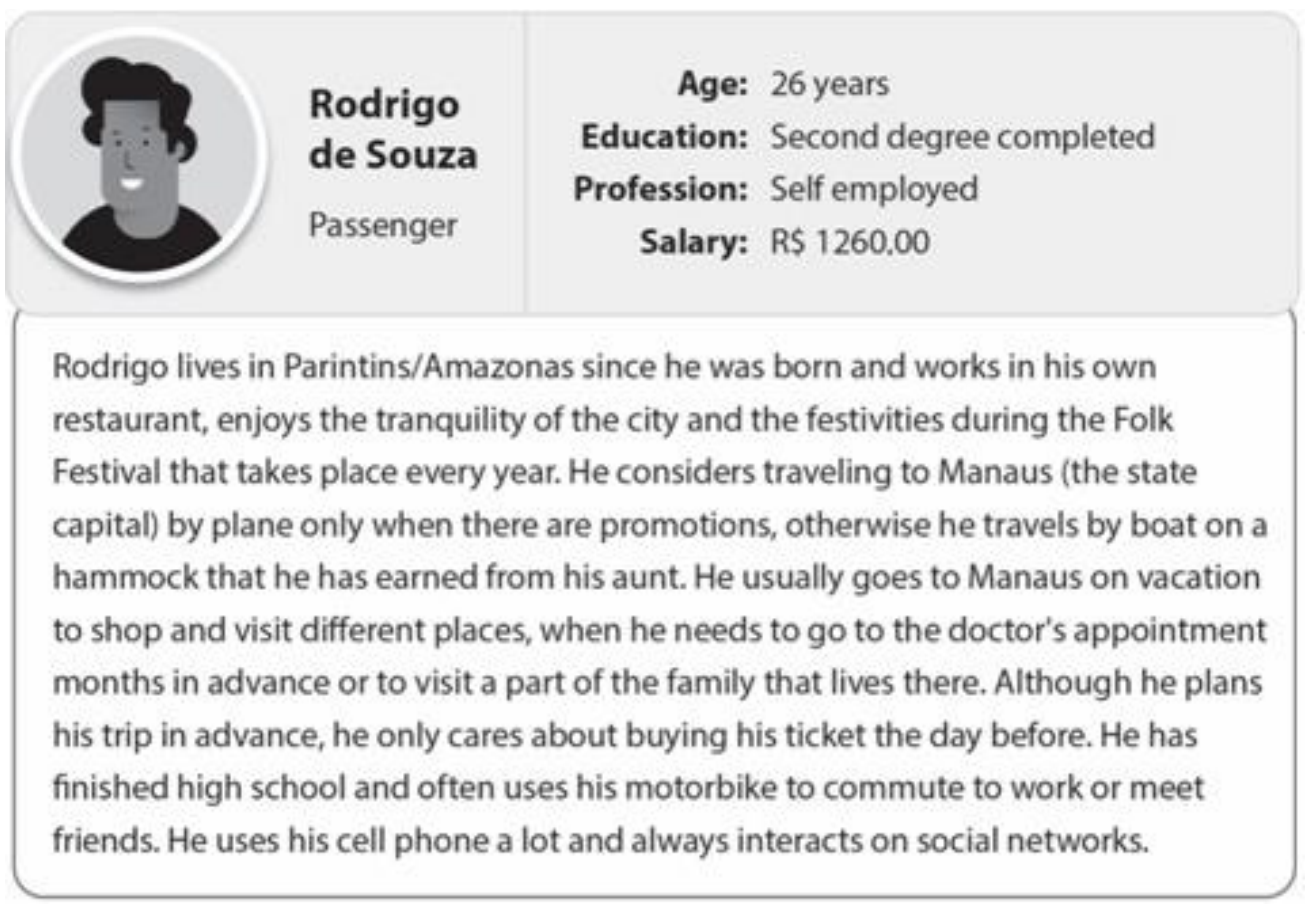

Figure 5: Persona

Based on the results of the Feature Analysis are listed in Figure 6 and the insights gained from the results of previous tools have defined the following features for the designed application.

- Allow the owner to define and change ticket prices, availability, commissions, discounts, departure and destination, departure and arrival time forecasts as well as other information relevant to the service provided.

- Allow the sale and consultation of cabin availability.

- Automate the issuance of the captaincy's passenger list.

- Apply discounts automatically on tickets for seniors or other cases that the law determines.

- Generate statistics with the trip data for shipowner's visualization.

- Provide intelligent search filters for ticket search.

- Issue the virtual ticket, support sharing and printing.

- Contact the vessel company.

- Support refunds or transfer tickets to another vessel in case of unforeseen events.

- Suggest event dates, promotions, most wanted dates.

\begin{tabular}{|c|l|}
\hline Name & \multicolumn{1}{c|}{ Functionalities } \\
\hline NetBarco & $\begin{array}{l}\text { Credit card payment by login with facebook / gmail. } \\
\text { Search for a time period, not an exact date. } \\
\text { Header to change search. }\end{array}$ \\
\hline
\end{tabular}




\begin{tabular}{|l|l|} 
& $\begin{array}{l}\text { Purchase Data, Rate Detail, and Price Confirmation Screen. } \\
\text { Reservation and ticketing function. } \\
\text { Auto-complete function in search fields in Source and Destination fields. } \\
\text { Display calendar in search field. } \\
\text { Informs vessel's departure location. } \\
\text { Selecting which ID to use. } \\
\text { Selecting what type of accommodation to buy (hammock or cabin). } \\
\text { Options for contacting the company. }\end{array}$ \\
\hline Embarcar & $\begin{array}{l}\text { Filter by Destination / Source. } \\
\text { Auto complete function in the Departure and Destination fields. } \\
\text { Displays boat information such as average capacity and available cabins. } \\
\text { Options for contacting the company. }\end{array}$ \\
\hline
\end{tabular}

Figure 6: Feature analysis result

With the main functions of the application defined, it was possible to build the structural organization chart (Figure 7) that presents the functions organized by hierarchy. From this organization chart it was possible to identify that the ideal would be to design two "modules" for the application. One for those looking to buy tickets, with search functions, management of purchased tickets, suggestions of destinations and promotions, passenger registration, forms of payment; and another aimed at the administrator (shipowner), with the functions of scheduling trips, distributing commissions, obtaining reports, checking tickets and issuing the captaincy's passenger list.

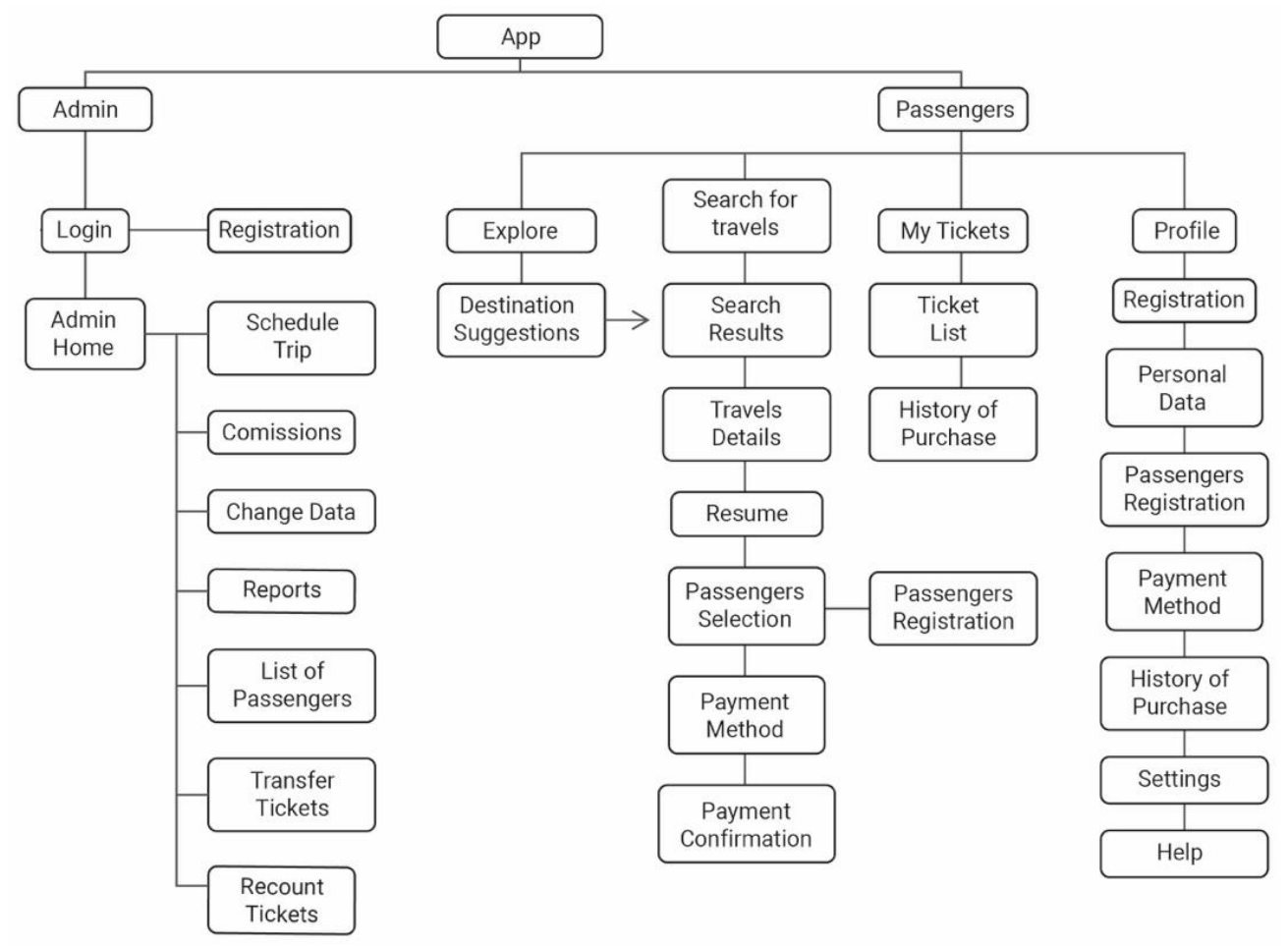

Figure 7: App structure organization chart 
Figure 8 shows the high-fidelity wireframes developed. These wireframes were used to conduct a pilot usability test.
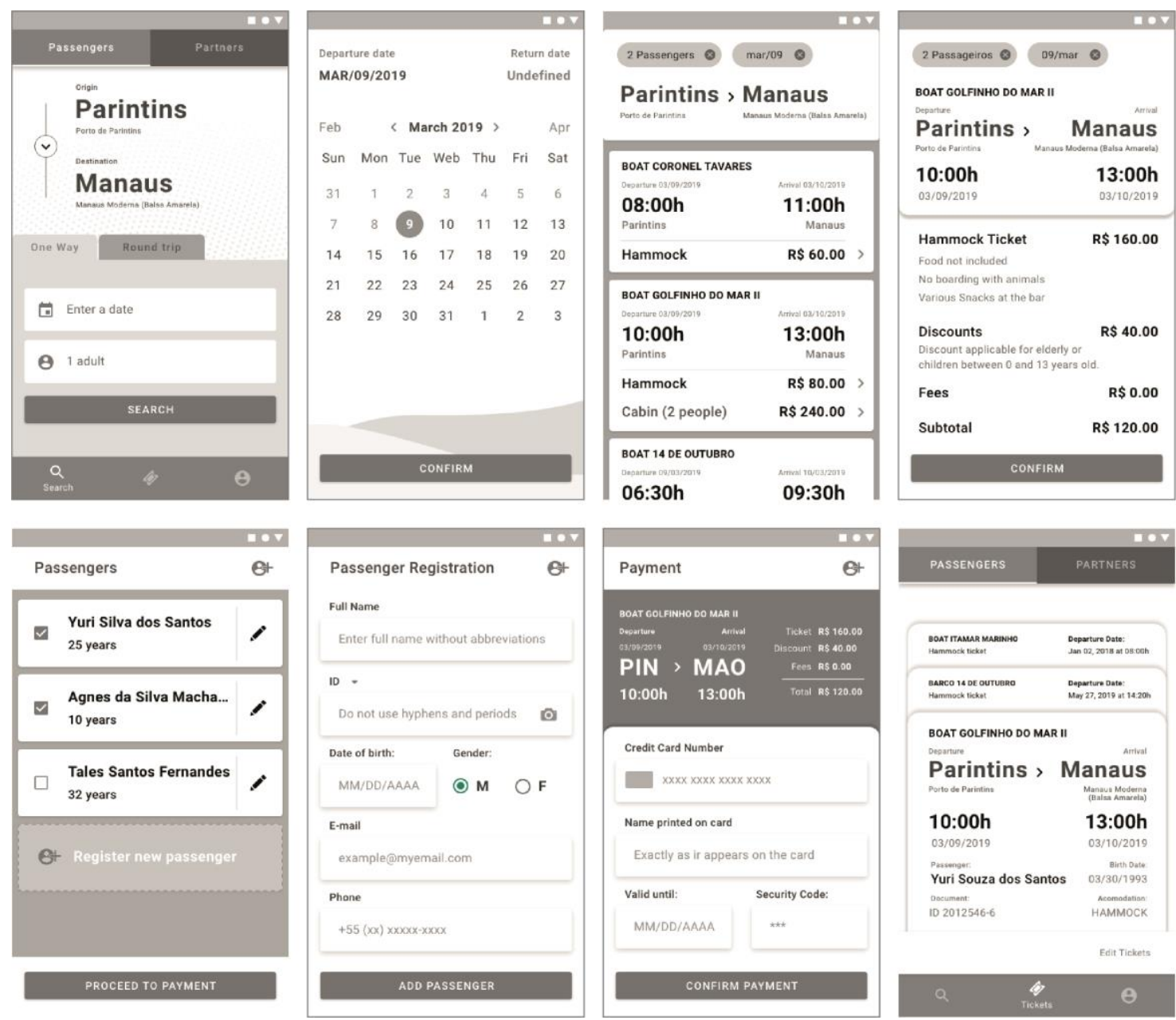

Figure 8: App Wireframes

The pilot test was applied with two people and, as a result, neither could perform the delimited tasks. According to their verbal report, the reasons for the failure of this initial test were mainly the need to memorize a lot of information to complete a task and the difficulty of finding segment change buttons (one way or round trip). Therefore, in this first test it was possible to understand that the tasks needed to be shorter and the interface more faithful to a possible final result for better comprehension.

To define the visual aspects of the interface, a mood board was created (Figure 9) that presents images that illustrate the context of the boats and symbolize the trips: the river, the boats, the biodiversity, the sunset and the vernacular typography. These, therefore, were elements used in the construction of the application's visual identity. 


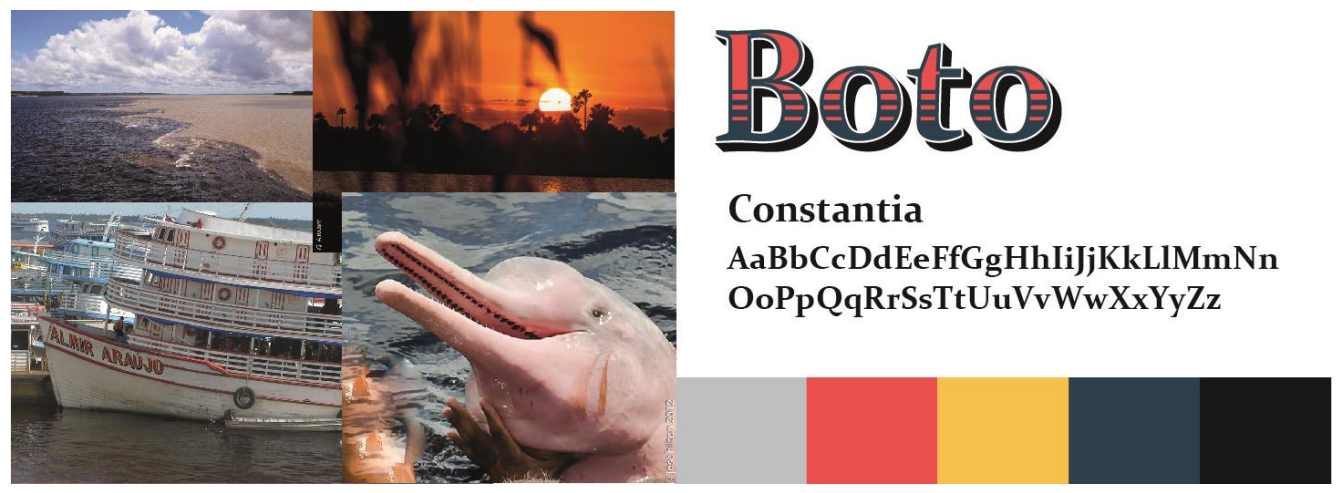

Figure 9: Author's Compilation ${ }^{1}$

The "Constantia" serif typography was chosen to be used in the brand because it is similar to the letters painted on the regional boats, a slight modification was made in the upper part of the typography to give movement to the shape, representing the river; the colors were taken from the images and adapted to a digital context to bring a modern look, the navy blue refers to the dark waters of the Black River and the sky, the yellow to the muddy waters of the Solimões River and the red represents the sky during the sunset.

In addition to visual references, building a moodboard helped define the name of the application. Boto is a mammal present in the waters of the rivers of the Amazon that is always seen during the travels. Besides being a charismatic symbol, it is the protagonist of an Amazonian legend that makes it a symbol of local folklore. It is a short word and easy to pronounce in many languages. In order to follow a different positioning of the existing ticket sales services, we chose to name the application "Boto" with the tagline "Boat Tickets".

Based on the visual identity, a study was carried out to define the image of the interface, illustrated by Figure 10. Defining the name and visual configuration of the application, improvements were applied to the previous wireframes considering the feedback obtained in the pilot test and insights of other techniques. Modifications were applied primarily prioritizing improved navigability and clarity of graphics.

\footnotetext{
${ }^{1}$ Composition made from images collected on the website creativecommons.org/: "Amazon river boat" by henribergius, licensed with CC BY-SA 2.0; "Amazon Sunset” by George Amaro, licensed under CC BY 2.0; "Dolphin-red, the pink dolphin - Red dolphin, Pink dolphin" by josé hilton, licensed with CC BY-NCSA 2.0; "Meeting of the Waters, Manaus, Brazil, 2002" by travfotos, licensed with CC BY-NC 2.0. To view a copy of these licenses, visit https://creativecommons.org/licenses/by-nc/2.0/
} 

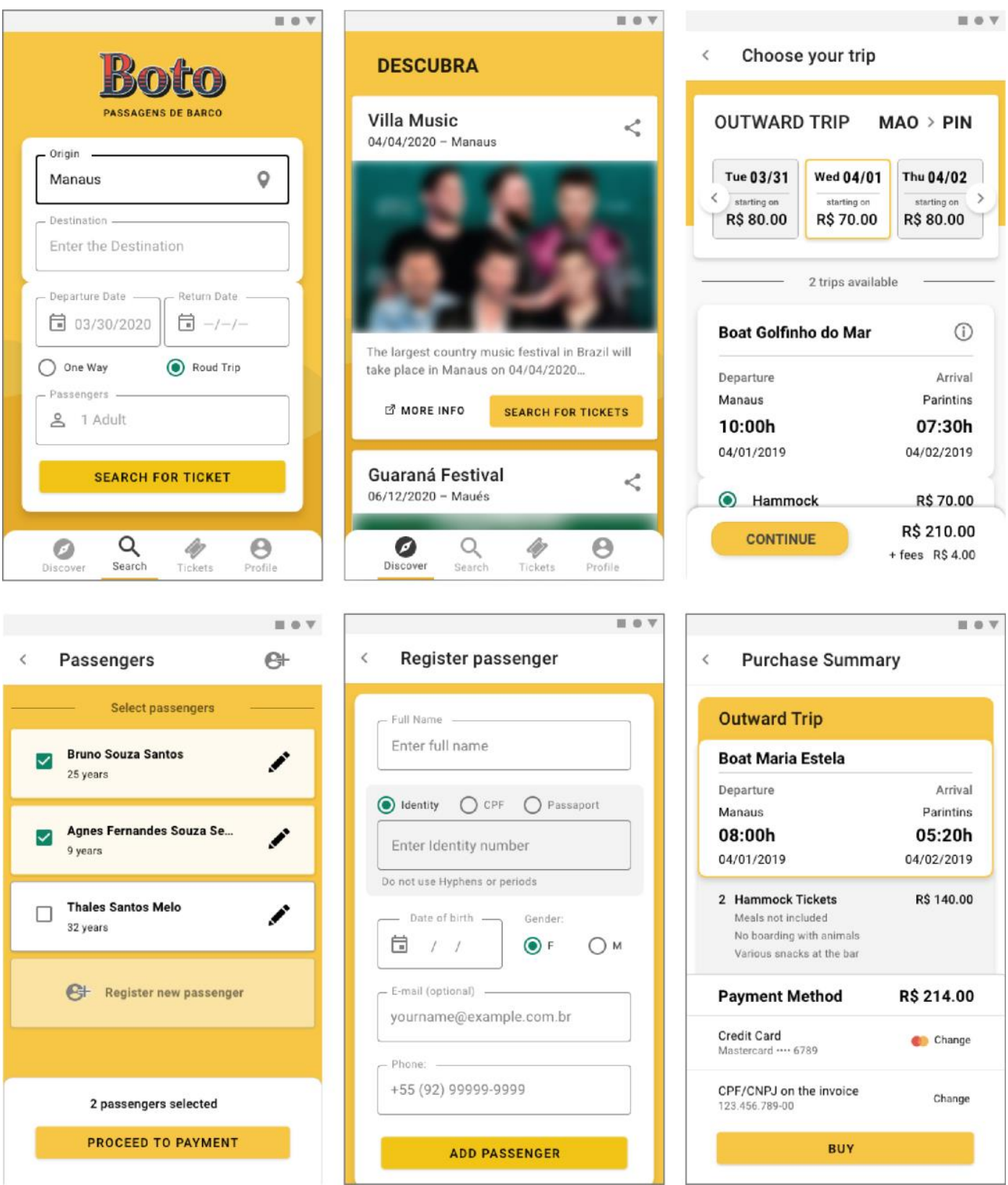

Figure 10: Final Interface

\section{$<\quad$ Choose your trip}

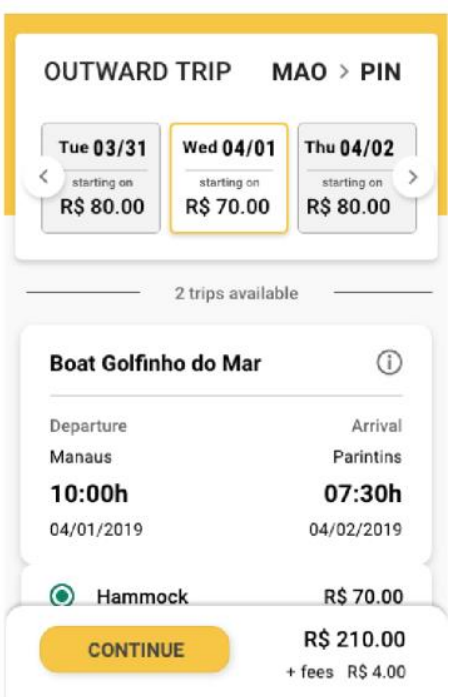

Finally, in the validation stage, the following data were collected (Figure 11). From all 10 users who tested the application prototype, 1 could not perform all the tasks requested and therefore did not participate in the final questionnaire. Regarding the average time of execution of each task, "register passengers" (1min 5s), followed by "choose trip" (54s) were the tasks that took the longest to complete. The user who took the longest to complete all tasks took 7 minutes and 27 seconds, while the fastest user took 1 minute and 22 seconds.

\begin{tabular}{|l|c|c|c|}
\hline \multicolumn{4}{|c|}{ Individual results } \\
\hline User & Success & Amount of clicks & Time of the test \\
\hline User \#1 & Yes & 183 & $7 \mathrm{~m} 26.8 \mathrm{~s}$ \\
\hline
\end{tabular}




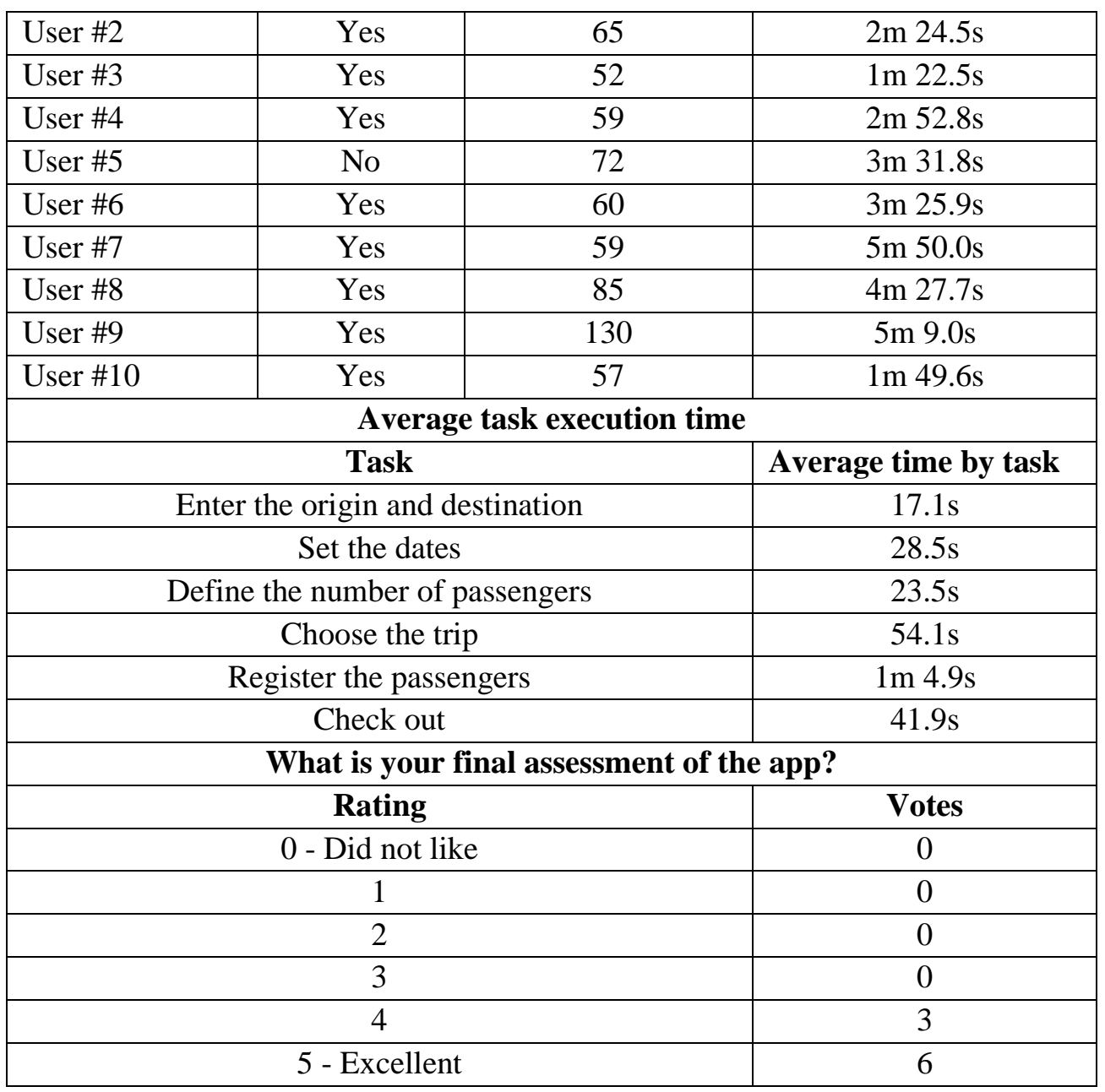

Figure 11: User test results

When asked which task was considered the most difficult, 5 users answered that they did not have difficulty in any task; 2 answered that they had difficulty in defining the dates of the trip, 1 had difficulty choosing the trip and 1 said they had difficulty in registering passengers.

On the issues related to the GUI, the most voted statements follow the following order. "The layout is nice" (8 votes), "I was able to locate myself within the system" (7 votes), "The app's functionality is clear and objective" ( 7 votes), "I could identify the buttons" (7 votes), "Colors made the interface nice" (6 votes), "Icon size is too small" (1 vote), and "Information is disorganized" (1 vote).

The application's final rating on a scale of " 0 - I didn't like it" to "5 - Excellent" was: 5 (6 votes), 4 (4 votes).

\section{Conclusion}

During the bibliographic research, in the first stages of the project, it was possible to identify that the Amazon river navigation scenario has several irregularities, among them the irregular administrative activities, the difficulty of the responsible agencies to supervise and regulate 
vessels, the difficulty of find information on travel and non-compliance with Article 28 of Law 10233/2001 and Article 6 of Law 8.987/1995 governing the quality-of-service provision. This scenario shows that although river navigation is of great importance in the Amazon region, there are several problems present and there have been few technological advances in recent years, especially if compared with other modes of transport.

Making use of information and communication technologies in the waterway sector is not an unprecedented task, but the amount of adversity present makes the conclusion of the objective a complex path. Being aware of these difficulties, it was possible to better understand the structure of the ticket sales service, and to elaborate an interface proposal that would improve the problems present in this process at informational and emotional levels. The functions defined for the application can be performed using technologies present in most smartphones and would considerably facilitate the control and offer of tickets sold since the proposed solution would not only decrease the number of tasks performed, but would change the market dynamics for both passengers, as well as shipowners and ticket sellers.

Much of the evolution of this research goes to the tests of the developed proposal, which underwent improvements after user feedback. While in the initial ideation phase the first test resulted in no user success rate, at the end of the design phase, users were able to perform the requested tasks and the system was generally rated as good and excellent.

Therefore, it can be concluded that the objective of developing a proposal for an interface for the boat ticket sales application from the Amazon region has been successfully achieved, but a plan has yet to be developed for the implementation of this interface in the sales process.

The biggest difficulty in implementing this service would be the cultural factor, as passengers are used to buying tickets in person. The habit makes it difficult to accept new ways of purchasing, so the proposed system can have the minimum initial function of just informing the data of each available trip and, later, with promotions and strategic suggestions, the purchasing function would no longer be a taboo for users.

\section{Acknowledgments}

The authors thank the support of the Amazonas State Research Support Foundation, called FAPEAM, as well as CAPES and UFAM.

\section{References}

ANTAQ Agência Nacional de Transportes Aquaviários. Caracterização da Oferta e da Demanda do Transporte Fluvial de Passageiros na Região Amazônica. Relatório Executivo. Brasília, 2013. 108 p.

ANTAQ Agência Nacional de Transportes Aquaviários. Caracterização da Oferta e da Demanda do Transporte Fluvial de Passageiros na Região Amazônica. Relatório Executivo. Brasília, 2017. 78 p. 
ANTAQ Agência Nacional de Transportes Aquaviários. Caracterização da Oferta e da Demanda do Transporte Fluvial de Passageiros e Cargas na Região Amazônica. Relatório Executivo. Brasília, 2018. 95 p.

ANTAQ Agência Nacional de Transportes Aquaviários. Pesquisa de Satisfação dos Usuários do Serviço de Transporte Longitudinal de Passageiros e Misto (Passageiros e Cargas) na Navegação Interior da Região Amazônica. Relatório Executivo. Brasilia, 2015.

BARBOSA, Evandro Brandão; PRADO, Adriane Pereira. Transporte Fluvial de Passageiros: Logística nos portos e itinerários do estado do Amazonas, Observatorio de la Economia Latinoamericana, n 194, 2014.

BARBOSA, Lucas Torres dos Santos Barbosa; SANTOS, José Teixeira de Araújo Neto; KUWAHARA, Nelson. Revisão Sistemática da Literatura Científica sobre Transporte Hidroviário no Estado do Amazonas. Scientia Amazonia, v. 4, n. 3, pp. 1-12, August, 2015.

BENCHIMOL, Samuel. Navegação e transporte na Amazônia. Manaus: Governo do Estado do Amazonas: Universidade do Amazonas: Associação Comercial do Amazonas, 1995

CALHEIROS, Carla Souza. Metodologia de tarifa para transporte fluvial de passageiros na Amazônia. 153p. Tese de Doutorado - Universidade Federal do Rio de Janeiro, Rio de Janeiro, 2010.

CLARO. Mapa de cobertura Claro. Disponível em: <https://www.claro.com.br/mapa-decobertura>. Acessado em: 03 de abr. de 2021.

COSTA, Nicole A.; HOLDER, Eric; MACKINNON, Scott N. Implementing human centred design in the context of a graphical user interface redesign for ship manoeuvring, International Journal of Human Computer Studies. Academic Press, v. 100, pp. 55-65. April 2017.

DAVID, Robert Carvalho de Azevedo. A dinâmica do Transporte Fluvial de Passageiros no estado do Amazonas. 122p. Dissertação de Mestrado - Universidade Federal do Amazonas. Manaus, 2010.

FERREIRA, Márcio Antônio Couto. Transporte Fluvial por embarcações mistas no Amazonas: Uma análise do trecho Manaus - Coari e Manaus - Parintins. 164p. Tese de Doutorado - Universidade Federal do Amazonas, Manaus, 2016.

FROTA, Cláudio Dantas. Gestão da qualidade aplicada às empresas prestadoras do serviço de transporte hidroviário de passageiros na Amazônia Ocidental: Uma proposta prática. 261p. Tese de Doutorado - Universidade Federal do Rio de Janeiro, Rio de janeiro, 2008.

IBGE Instituto Brasileiro de Geografia e Estatística. Pesquisa Nacional por amostra de domicílios contínua: Acesso à internet e à televisão e posse de telefone móvel celular para uso pessoal 2018. Análise de Resultados. Rio de Janeiro: IBGE, 2018, 146 p.

LINS, Nadja Vanessa Miranda; CAMELO, Alcilene Moreira; DACOL, Silvana. Caracterização do Transporte Fluvial de Passageiros na Amazônia, In: COPINAVAL, Congreso Panamericano de Ingenieria Naval, 20., São Paulo, 2007. Anais [...]. São Paulo, 2007, p. 11.

MARSILIO, Maguil. A interferência da internet na competitividade das agências de viagens e turismo na cidade de São Paulo. 191p. Dissertação de mestrado - Universidade de Caxias do Sul, Caxias do Sul, 2014.

MEREGE, Fernando. Indicadores da navegação hidroviária mista na região amazônica. In: SOBENA - Seminário de transporte e Desenvolvimento hidroviário Interior, 7, 2011, Porto Alegre, 7 SOBENA, 2011. 
MEURER, Heli; SZABLUK, Daniela. Projeto E: aspectos metodológicos para o desenvolvimento de projetos dígito-virtuais, Ação Ergonômica: Revista da Associação Brasileira de Ergonomia, v.5, n. 2, pp. 1-9, 2010.

MOURA, Joel Brito. Mapeamento dos custos para tarifa de transporte no trecho Manaus - Barcelos: Um estudo de caso. 177p. Dissertação de Mestrado - Universidade Federal do Amazonas, Manaus, 2017.

MORAES, Rita de Cássia Monteiro de. Ferramenta de Avaliação do Transporte Hidroviário de Passageiros da Região Amazônica. 2013. 121p. Dissertação de Mestrado Universidade Federal do Pará, Belém, 2013

ROTH, Robert. E.; HART, David; MEAD, Rashauna; QUINN, Chloë. Wireframing for interactive \& web-based geographic visualization: designing the NOAA Lake Level Viewer. Cartography and Geographic Information Science. Taylor \& Francis, v. 44, n. 4, p. 338 357. Jun 2017.

STICKDORN, Marc; SCHNEIDER, Jakob. Isto é design thinking de serviços. 1 ed. Porto Alegre: Bookman. 2014.

\section{Sobre os autores}

\section{Tiago Kimura Bentes}

Possui graduação em Design pela Universidade Federal do Amazonas (2014). Mestrado profissional em Design Tecnologia e Inovação pela Universidade Federal do Amazonas e atualmente é professor substituto do Departamento de Design e Expressão Gráfica na Universidade Federal do Amazonas.

https://orcid.org/0000-0002-1098-4432.

\section{Nelson Kuwahara}

Professor Associado da Universidade Federal do Amazonas - UFAM. Coordenador do Laboratório TRANSPORTAR. Coordenador do Programa de Pós-Graduação em Design PPGD/UFAM. Graduado em Engenharia Mecânica, Mestrado em Planejamento de Sistemas Energéticos, Doutorado em Engenharia de Transportes.

https://orcid.org/0000-0002-4572-9415. 